\title{
Capsaicin on the viability of random-pattern skin flaps in rats ${ }^{1}$
}

\author{
Capsaicina na viabilidade de retalhos isquêmicos randômicos em ratos
}

\author{
Gustavo Roberto de Godoy", Richard Eloin Liebano", Juliana Barbosa Corrêa ${ }^{I I I}$, Bernardo Hochman ${ }^{\text {IV }}$, Lydia Masako Ferreirav \\ ${ }^{I}$ Master, Plastic Surgery Division, UNIFESP, Sao Paulo, Brazil. \\ ${ }^{\text {II }} \mathrm{PhD}$, Volunteer Faculty, Plastic Surgery Division, UNIFESP, Sao Paulo. Full Professor, Physical Therapy Department, City University of Sao Paulo \\ (UNICID), Brazil. \\ III Student of Extension Course in Plastic Surgery, UNIFESP, Sao Paulo, Brazil. \\ Iv $\mathrm{PhD}$, Affiliate Professor, Plastic Surgery Division, UNIFESP, Sao Paulo, Brazil. \\ ${ }^{\vee}$ PhD, Head Department of Surgery, Full Professor Plastic Surgery Division, UNIFESP, Sao Paulo, Brazil.
}

\begin{abstract}
Purpose: To evaluate the effects of capsaicin on the viability of ischemic random-pattern skin flaps in rats. Methods: Forty EPM1-Wistar rats were randomized into two groups of 20 animals each, the capsaicin group and the control group. A random-pattern skin flap measuring $10 \mathrm{x} 4 \mathrm{~cm}$ was raised and a plastic barrier was placed between the flap and the donor site. After the surgical procedure, the control group was treated with an inert vehicle in the form of a cream applied uniformly to a rayon bandage which, in turn, was applied to the surface of the skin flap. The capsaicin group was treated in the same way, but in this case capsaicin was added to the cream. This procedure was repeated for two consecutive days. Results: There was a significantly smaller amount of flap necrosis in the capsaicin group $(35.07 \%)$ than in the control group $(44.75 \%)(p=0.035)$. Conclusion: Topical administration of capsaicin improved the viability of ischemic random-pattern skin flaps in rats.
\end{abstract}

Key words: Capsaicin. Surgical Flaps. Neuropeptides. Necrosis. Rats.

RESUMO

Objetivo: Avaliar os efeitos da capsaicina na viabilidade de retalhos isquêmicos randômicos em ratos. Métodos: Quarenta ratos EPM1-Wistar foram distribuídos ao acaso em dois grupos de 20 animais cada, um grupo capsaicina e um grupo controle. Um retalho isquêmico randômico medindo $10 \mathrm{x} 4 \mathrm{~cm}$ foi elevado e uma barreira plástica foi colocada entre o retalho e a área doadora. Após o procedimento cirúrgico, o grupo controle foi tratado com um veículo inerte sob a forma creme aplicado uniformemente sobre uma atadura de rayon, que, por sua vez, foi aplicada à superfície do retalho. O grupo capsaicina foi tratado da mesma forma, porém a capsaicina foi adicionada ao creme. Este procedimento foi repetido por dois dias consecutivos. Resultados: Houve uma quantidade significativamente menor da necrose do retalho no grupo capsaicina $(35,07 \%)$ comparado ao grupo controle $(44,75 \%)(p=0,035)$. Conclusão: A administração tópica da capsaicina melhorou a viabilidade de retalhos isquêmicos randômicos em ratos.

Descritores: Capsaicina. Retalhos Cirúrgicos. Neuropeptídeos. Necrose. Ratos.

${ }^{1}$ Research performed at Department of Surgery, Plastic Surgery Division, Federal University of Sao Paulo (UNIFESP), Brazil.

\section{Introduction}

Necrosis of skin flaps may be attributed to extrinsic and intrinsic factors. Among the intrinsic factors, the best known is the inadequate vascular perfusion of the flap ${ }^{1,2}$. In many studies, drugs such as antiadrenergics ${ }^{3,4}$, vasodilators ${ }^{5,6}$, antispasmodics ${ }^{7}$, anticoagulants and calcium-channel blockers ${ }^{8}$ have been used to improve flap viability. However, undesirable side effects, high drug prices, restricted availability or the need for a long-term treatment during the preoperative period make some drugs impractical for clinical use ${ }^{8}$.
In other studies, researchers tried to improve the viability of skin flaps by topically applying medicines, seeking to increase local action and minimize systemic action, thereby reducing side effects $^{6,9}$. Among these drugs is capsaicin ${ }^{9-11}$, a substance that, in general, promotes vasodilatation and inhibits platelet $\operatorname{aggregation}^{12,13}$.

In this context, capsaicin has the potential to be administered topically in the postoperative period, and may improve the viability of ischemic skin flaps by transdermal action. However, in these studies ${ }^{10,11}$ the skin flap remained covered with bandage containing capsaicin throughout the treatment period, 
preventing the continuous evaluation of the signs of ischemia and necrosis development. Also in most studies the capsaicin treatment usually varies from 6 to 7 days in the postoperative period ${ }^{9-11}$. These limitations make it potentially difficult to determine the applicability of this method to clinical practice. Thus, the present study was designed to investigate the usefulness of a different method of capsaicin application, with the overall goal of optimizing the technique so capsaicin may be used clinically to treat ischemic skin flaps in the future. Therefore, the purpose of this study was to evaluate the effects of capsaicin on the viability of ischemic random-pattern skin flaps in rats.

\section{Methods}

Forty adult male EPM1-Wistar rats (Rattus norvegicus albinus), weighing between 230 and $380 \mathrm{~g}$, were used in the study. The animals were housed in individual cages on a 12:12 hour light-dark cycle, and fed standard rat chow and water ad libitum. This research was approved by the Research Ethics Committee at the UNIFESP/EPM, Sao Paulo, Brazil, under the process number 0381/03.

The animals were randomly assigned by lottery to either the capsaicin or control groups of 20 animals each.

The rats were anesthetized intraperitoneally with tiletamine hydrochloride $(25 \mathrm{mg} / \mathrm{kg})$ and zolazepam hydrochloride $(25 \mathrm{mg} / \mathrm{kg})$ for surgery, and prior to the application of capsaicin on the two consecutive days. Following anesthesia, each rat was placed on a flat surface with legs extended, the back was shaved, and the skin flap was outlined. After, a 10 x 4-cm, cranially-based dorsal skin flap was raised ${ }^{14}$; its cranial limit was determined by a transverse line at the level of the angles of the scapulae. The skin flap was dissected to the deep fascia and a plastic barrier was placed between the flap and its bed (donor site) ${ }^{15,16}$. The flap was returned to its original position and sutured in place with simple interrupted 4-0 monofilament nylon sutures ${ }^{17}$. A solution containing $1 \mathrm{~g}$ of capsaicin powder (dissolved in $10 \mathrm{ml}$ of $70 \%$ ethanol) was added to a cream, consisting of cetostearyl alcohol (Lanette ${ }^{\circledR}$ wax cream) and mineral oil, to a concentration of $0.2 \%$ (200 $\mathrm{mg}$ of capsaicin per $100 \mathrm{~g}$ of cream). After surgery, $2 \mathrm{~g}$ of cream without capsaicin (control group) or $2 \mathrm{~g}$ of the same cream with $0.2 \%$ capsaicin (capsaicin group) was uniformly applied to a rayon bandage. Following, the bandage was carefully positioned on the skin flap (Figure 1) in order to prevent its contact with sutures on the flap edges. After 35 minutes, the rayon bandage was removed and the animal was returned to the cage. This application was repeated for two consecutive days in all animals of both groups.

The percentage of skin flap necrosis was measured on the seventh postoperative day, using the paper template method ${ }^{18}$ by an observer who was blind to the treatment condition.

Statistical analysis was performed using Student's t-test at a significance level of $5 \%(\mathrm{p} \leq 0.05)$.

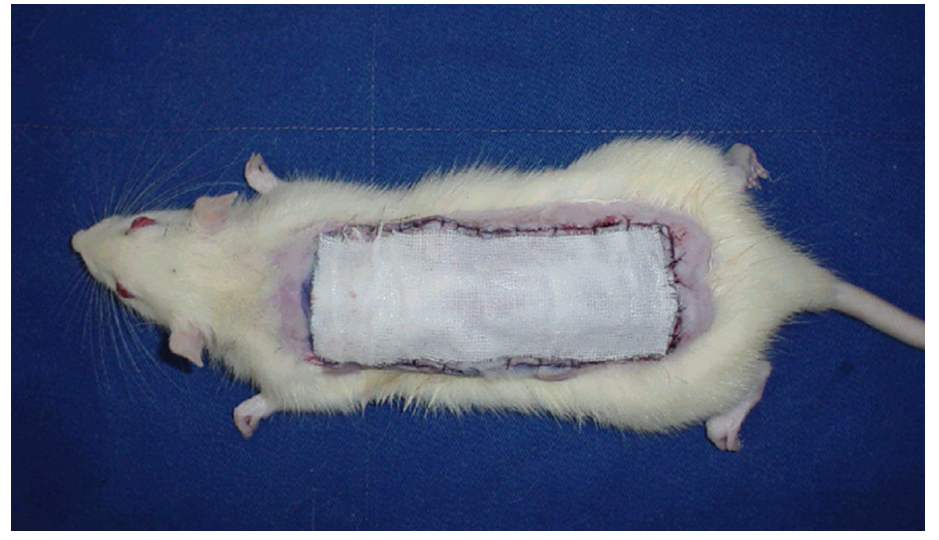

FIGURE 1 - Rayon bandage containing capsaicin or inert vehicle placed on the skin flap

\section{Results}

There was a significantly smaller amount of flap necrosis $(p=0.035)$ in the capsaicin group than in the control group. The percentages of necrotic area (mean \pm standard deviation) in the capsaicin and control groups were $35.07 \pm 14.67 \%$ and $44.75 \pm 12.81 \%$, respectively (Figure 2 ).

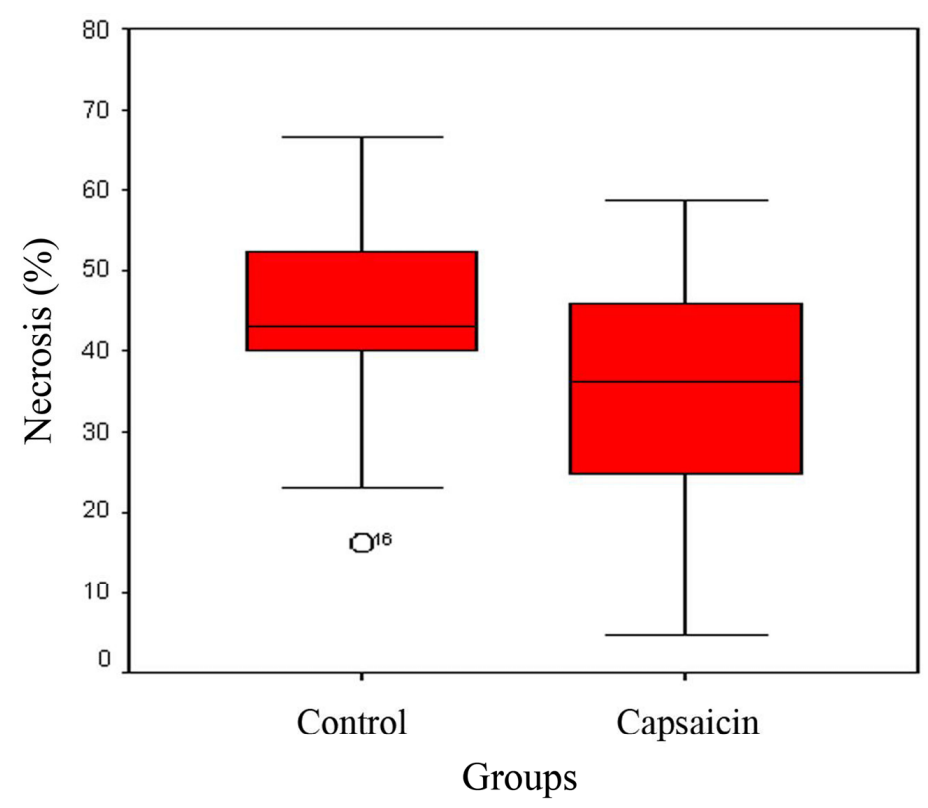

FIGURE 2 - Distribution of the percentage of necrotic area per group

Student's t-test

Control group $\mathrm{x}$ capsaicin group $(\mathrm{p}=0.035)$ 


\section{Discussion}

Skin flap necrosis after reconstructive surgeries remains an important problem for plastic surgeons ${ }^{17}$. In view of the physiological mechanisms of ischemia that lead to flap necrosis and the effects of capsaicin, it is important to study this substance with the aim of improving the viability of ischemic randompattern skin flaps. Iinuma and Sawada ${ }^{10}$ attributed the improvement in skin flap viability after topical application of capsaicin to platelet disaggregation. On the other hand, Miyawaki et al. ${ }^{9}$ concluded that the beneficial effect of capsaicin in the skin flap viability is due to vasodilation caused by the release of vasodilator neuropeptides, such as substance P (SP) and calcitonin gene-related peptide (CGRP), and increased neovascularization ${ }^{4,19,20}$.

The amount of capsaicin and application time used in our study were based on the work by Wang et al. ${ }^{21}$ Capsaicin was indirectly applied to the skin; it was first uniformly applied with a spatula to a rayon bandage (which was slightly smaller than the flap dimensions) to prevent manual contact that could alter the $\mathrm{pH}$ of the substance. The rayon bandage was removed 35 minutes after application to keep the bandage from slipping while the animal was caged and to prevent its removal by the animal, which would interrupt the treatment process and make our study different from other similar studies in the literature ${ }^{10,11}$.

Many authors have shown that percutaneous absorption of capsaicin through animal and human skin occurs within 3 to 4 minutes after application, and produces maximal vasodilation at about 30 to 34 minutes ${ }^{21-25}$.

The 3-day application period was chosen based on studies of transcutaneous electrical nerve stimulation ${ }^{4,17}$, and iontophoresis of CGRP ${ }^{26}$. Although these modalities of treatment differ from that used in the present study, their mechanisms of action by which the viability of skin flaps is enhanced are similar to that of capsaicin, that is, vasodilation induced by neuropeptides release.

The mean percentage of necrotic area was $35.07 \%$ in the capsaicin group and $44.75 \%$ in the control group. There was a significant difference between groups $(p=0.035)$, leading to the conclusion that capsaicin improved the ischemic condition of the random-pattern skin flaps, even if the postoperative treatment period (3 days) was shorter than in previous studies ${ }^{9-11}$.

Capsaicin in concentrations of continuous topical administration causes depletion of neurotransmitters, leading to a reversible interruption of the conductivity of sensory nerve fibers. For this reason, capsaicin is widely used in the treatment of pain ${ }^{13,25,27-29}$. However, further studies on the application of capsaicin in humans are needed in order to adapt the model, and determine the concentration of capsaicin suitable for human use, since no study on this subject was found in the literature.

\section{Conclusion}

Topical administration of capsaicin improved the viability of ischemic random-pattern skin flaps in rats.

\section{References}

1. Kerrigan CL. Skin flap failure: pathophysiology. Plast Reconstr Surg. 1983;72(6):766-77.

2. Atalay C, Koçkaya EA, Cetin B, Kismet K, Akay T. Efficacy of topical nitroglycerin and transcutaneous electrical nerve stimulation on survival of random-pattern skin flaps in rats. Scand J Plast Reconstr Surg Hand Surg. 2003;37(1):10-3.

3. Jurell G, Jonsson CE. Increased survival of experimental skin flaps in rats following treatment with antiadrenergic drugs. Scand J Plast Reconstr Surg. 1976;10(3):169-72.

4. Kjartansson J, Lundeberg T, Samuelson UE, Dalsgaard CJ, Hedén P. Calcitonin gene-related peptide (CGRP) and transcutaneous electrical nerve stimulation (TENS) increase cutaneous blood flow in a musculocutaneous flaps in the rat. Acta Physiol Scand. 1988;134(1):89-94.

5. Erçöçen AR, Apaydin I, Emiroglu M, Gültan SM, Ergün H, Yormuk E. The effects of L-arginine and iloprost on the viability of random skin flaps in rats. Scand J Plast Reconstr Surg Hand Surg. 1998;32(1):19-25.

6. Smith DK, Dolan RW. Effects of vasoactive topical agents on the survival of dorsal skin flaps in rats. Otolaryngol Head Neck Surg. 1999;121(3):220-3.

7. Ergün H, Çilinger MG, Apaydin I, Erçöçen AR, Tulunay FC. The effect of dipyrone on survival of skin flaps. Scand J Plast Reconstr Surg Hand Surg. 2001;35(1):19-22.

8. Davis ER, Wachholz JH, Jassir D, Perlyn CA, Agrama MH. Comparison of topical anti-ischemic agents in the salvage of failing random-pattern skin flaps in rats. Arch Facial Plast Surg. 1999;1(1):27-32.

9. Miyawaki T, Jackson IT, Bier UC, Andrus L, Williams F, Bradford M. The effect of capsaicin ointment on skin for the survival of cutaneous flap. Eur J Plast Surg. 2001;24:28-30.

10. Iinuma T, Sawada Y. Topical application of capsaicin and flap survival. Br J Plast Surg. 1996;49(5):319-20.

11. Sawada Y, Yotsuyanagi T, Yokoi K, Ishita K. Plaster containing capsaicin increase the survival of experimental flaps: effects of post- and preoperative administration. Eur J Plast Surg. 1997;20:256-9.

12. Hogaboam CM, Wallace JL. Inhibition of platelet aggregation by capsaicin. An effect unrelated to actions on sensory afferent neurons. Eur J Pharmacol. 1991;202(1):129-31.

13. Szallasi A, Blumberg PM. Vanilloid (capsaicin) receptors and mechanisms. Pharmacol Rev. 1999;51(2):159-211.

14. McFarlane, RM, DeYoung G, Henry RA. The design of pedicle flap in the rat to study necrosis and its preventions. Plast Reconstr Surg. $1965 ; 35: 177-82$

15. Korlof B, Ugland O. Flaps and flap necrosis. Improving the circulation in skin flaps with complamin and with dicoumarol: animal experiments. Acta Chir Scand. 1966;131:408-12.

16. Kaufman T, Angel MF, Eichenlaub EH, Levin M, Hurwitz DJ, Futrell JW. The salutary effects of the bed on the survival of experimental flaps. Ann Plast Surg. 1985;14:64-73.

17. Liebano RE, Ferreira LM, Sabino Neto M. The effect of transcutaneous electrical nerve stimulation on the viability of random skin flaps in rats. Can J Plast Surg. 2002;10:151-4.

18. Sasaki GH, Pang CY. Hemodynamics and viability of acute neurovascular island skin flap in rats. Plast Reconstr Surg. 1980;65(2):152-8.

19. Jernbeck J, Dalsgaard CJ. Calcitonin gene-related peptide treatment of flaps with compromised circulation in humans. Plast Reconstr Surg. 1993;91(2):236-44.

20. Gherardini G, Gürlek A, Evans GR, Milner SM, Matarasso A, Wassler M, Jernbeck J, Lundeberg T. Venous ulcers: improved healing by iontophoretic administration of calcitonin gene-related peptide and vasoactive intestinal polypeptide. Plast Reconstr Surg. 1998;101(1):90-3. 
21. Wang YY, Hong CT, Chiu WT, Fang JY. In vitro and in vivo evaluations of topically applied capsaicin and nonivamide from hydrogels. Int J Pharm. 2001;224(1-2):89-104.

22. Magnusson BM, Koskinen LO. Effects of topical application of capsaicin to human skin: a comparison of effects evaluated by visual assessment, sensation registration, skin blood flow and cutaneous impedance measurements. Acta Derm Venereol. 1996;76(2):129-32.

23. Magnusson BM, Koskinen LD. In vitro percutaneous penetration of topically applied capsaicin in relation to in vivo sensation responses. Int $\mathrm{J}$ Pharm. 2000;195(1-2):55-62.

24. Fang JY, Leu YL, Wang YY, Tsai YH. In vitro topical application and in vivo pharmacodynamic evaluation of nonivamide hydrogels using Wistar rat as an animal model. Eur J Pharm Sci. 2002;15(5):417-23.
25. Robbins WR, Staats PS, Levine J, Fields HL, Allen RW, Campbell JN, Pappagallo M. Treatment of intractable pain with topical large dose capsaicin: preliminary report. Anesth Analg. 1998;86(3):579-83.

26. Esteves Junior I, Ferreira LM, Liebano RE. Peptídeo relacionado ao gene da calcitonina por iontoforese na viabilidade de retalho cutâneo randômico em ratos. Acta Cir Bras. 2004;19(6):626-9.

27. Craft RM, Porreca F. Treatment parameters of desensitization to capsaicin. Life Sci. 1992;51(23):1767-75.

28. Rayner HC, Atkins RC, Westerman RA. Relief of local stump pain by capsaicin cream. Lancet. 1989;2(8674):1276-7.

29. Cannon DT, Wu Y. Topical capsaicin as an adjuvant analgesic for the treatment of traumatic amputee neurogenic residual limb pain. Arch Phys Med Rehabil. 1998;79(5):591-3.

\section{Correspondence:}

Richard Eloin Liebano

Universidade Federal de São Paulo, Disciplina de Cirurgia Plástica

Rua Napoleão de Barros, $715 / 4^{\circ}$ andar

04024-002 São Paulo - SP Brasil

Phone: (55 11)5576-4118

Fax: (55 11) 5571-6579

liebano@gmail.com

\section{How to cite this article}

Godoy GR, Liebano RE, Corrêa JB, Hochman B, Ferreira LM. Capsaicin on the viability of random-pattern skin flaps in rats. Acta Cir Bras. [serial on the Internet] 2010 Sept-Oct;25(5). Available from URL: http://www.scielo.br/acb 